\title{
Risk factors associated with Bovine Viral Diarrhea Virus (BVDV) infection in the semiarid of the state of Paraíba, in the northeast region of Brazil
}

\author{
Fatores de risco associados à infecção pelo vírus da diarreia viral \\ bovina (BVDV) no semiárido do estado da Paraíba, região nordeste \\ do Brasil
}

\author{
Ana Luisa Alves Marques ${ }^{1}$; Adriana Cunha de Oliveira Assis²; Sara Vilar Dantas \\ Simões ${ }^{3}$; Mikael Leandro Duarte de Lima Tolentino ${ }^{4}$; Sérgio Santos de Azevedo ${ }^{3 *}$
}

\begin{abstract}
Bovine viral diarrhea virus (BVDV) has become an important viral infectious agent in cows and is considered endemic in many regions. This study aimed to determine the epidemiological status of BVDV in bovine herds in the semiarid of the state of Paraíba, in northeastern Brazil, by determining the frequency of anti-BVDV antibodies and risk factors associated with the infection. We tested 359 cows from 20 farms. Three had a history of clinically suspected bovine viral diarrhea (BVD) or mucosal disease (MD), whereas the other 17 locations were randomly selected. Detection of anti-BVDV antibodies was performed by indirect ELISA using a commercial kit (IDEXX BVDV p80 Ab Test). Risk factor analysis was performed in two steps, univariate and multivariate analysis. Seven samples were considered suspicious and were excluded from the analysis of seropositive animals. Of 352 animals, $141(40.1 \% ; 95 \% \mathrm{CI}=34.9 \%-45.2 \%)$ were seropositive. Of the 20 farms analyzed, $19(95 \%)$ had seropositive animals and the frequency of seropositivity per farm varied between $4.5 \%$ and $85.7 \%$. The risk factors identified were as follows: area $\leq 120$ hectares $(\mathrm{OR}=3.06 ; 95 \% \mathrm{CI}=1.43-6.53)$, high animal density $(\mathrm{OR}=3.48 ; 95 \% \mathrm{CI}=1.24-9.79)$, weaning age $\leq 60$ days $(\mathrm{OR}=10.99 ; 95 \% \mathrm{CI}$ $=1.31-91.9)$, exchange of animals $(\mathrm{OR}=4.95 ; 95 \% \mathrm{CI}=2.08-11.8)$, calf mortality $>5 \%(\mathrm{OR}=2.33$; $95 \% \mathrm{CI}=1.07-5.11)$, and use of natural breeding and artificial insemination $(\mathrm{OR}=3.06 ; 95 \% \mathrm{CI}=1.22$ - 7.67). It was suggested that to avoid the transmission of BVDV infection in bovine herds in the Sertão of Paraíba, it is important to prevent identified associated risk factors and to perform further studies, identifying persistently infected animals.
\end{abstract}

Key words: BVDV. Control. Viral diseases. Epidemiology.

\section{Resumo}

O vírus da diarreia viral bovina (BVDV) tem emergido como um dos mais importantes agentes virais infecciosos em bovinos, sendo considerado endêmico em várias regiões. Objetivou-se com este estudo determinar a situação epidemiológica da infecção pelo BVDV em rebanhos bovinos do semiárido paraibano, nordeste do Brasil, pela determinação da frequência de anticorpos anti-BVDV

\footnotetext{
1 Discente do Curso de Doutorado do Programa de Pós-Graduação em Medicina Veterinária, Universidade Federal de Campina Grande, UFCG, Patos, PB, Brasil. E-mail: analuisa vet@hotmail.com

2 Médica Veterinária, Prefeitura Municipal de Pombal, Pombal, PB, Brasil. E-mail: drica.cvet@yahoo.com.br

3 Profs., Programa de Pós-Graduação em Medicina Veterinária, UFCG, Patos, PB, Brasil. E-mail: saravdsimoes@gmail.com; sergio@vps.fmvz.usp.br

4 Discente do Curso de Graduação em Medicina Veterinária, UFCG, Patos, PB, Brasil. E-mail: mikaeltolentino@gmail.com

* Author for correspondence
} 
e de fatores de risco associados à infecção. Foram utilizadas 359 vacas de 20 propriedades rurais, sendo três propriedades com histórico de suspeita clínica de diarreia viral bovina (BVD) ou doença das mucosas (DM) e 17 sorteadas aleatoriamente. A detecção de anticorpos anti-BVDV foi realizada com kit comercial ELISA indireto (IDEXX BVDV p80 Ab Test) e a análise de fatores de risco foi efetuada em duas etapas: análise univariada e análise multivariada. Sete amostras foram consideradas suspeitas e foram excluídas do cálculo da frequência de animais soropositivos. Dos 352 animais, 141 (40,1\%; IC $95 \%=34,9 \%-45,2 \%)$ foram soropositivos. Das 20 propriedades analisadas, em 19 (95\%) havia animais soropositivos e a frequência de soropositividade por propriedade variou de $4,5 \%$ a $85,7 \%$. Os fatores de risco identificados foram: área $\leq 120$ ha $(\mathrm{OR}=3,06$; IC $95 \%=1,43-6,53)$, alta densidade de animais $(\mathrm{OR}=3,48$; IC 95\% = 1,24 - 9,79), idade ao desmame até 60 dias $(\mathrm{OR}=10,99$; IC 95\% $=$ $1,31-91,9)$, permuta de animais $(\mathrm{OR}=4,95$; IC $95 \%=2,08-11,8)$, mortalidade de bezerros $>5 \%(\mathrm{OR}$ $=2,33$; IC $95 \%=1,07-5,11)$ e utilização de monta natural mais inseminação artificial $(\mathrm{OR}=3,06$; IC $95 \%=1,22-7,67)$. Sugere-se que para evitar a difusão da infecção pelo BVDV em rebanhos bovinos do sertão paraibano é importante a correção dos fatores de risco identificados, bem como é necessário conduzir estudos para a identificação de animais persistentemente infectados.

Palavras-chave: BVD. Controle. Doenças virais. Epidemiologia.

\section{Introduction}

The dissemination characteristics of viral infections are of constant concern for veterinarians and producers. Pestiviruses are potentially the viruses that most frequently affect bovines (SANDVIK, 1999). In this context, the bovine viral diarrhea virus (BVDV) has become an important viral infectious agent of bovines, and is considered endemic in many regions (BACHOFEN et al., 2013). It is believed that the economic impact of these infections cannot be estimated, as the virus causes sudden losses due to subfertility and immunosuppression in infected animals (RODNING et al., 2012).

Bovine viral diarrhea (BVD) is caused by an RNA-virus of the Flaviviridae family, genus Pestivirus. Clinical manifestations of this virus can include respiratory disease, gastroenteric disease, hemorrhagic syndrome with thrombocytopenia, abortions, temporary infertility, congenital defects, immunosuppression, and mucosal diseases (MD) (GROOMS; KEILEN, 2002). However, reproductive problems are considered the most important, as BVDV exhibits tissue tropism to germ cells. In addition, viral activity in the ovarian tissue can lead to failures or delays in ovulation during estrus, which can result in low fertilization rates. When infected at the beginning of pregnancy, females can lose the embryo or fetus (abortion and/or mummification). When infected between 40 and 125 days of pregnancy, females can give birth to persistently infected (PI) animals, which are responsible for the maintenance of the virus in herds (BROWNLIE, 2002; GROOMS, 2004). The virus also shows tropism for lymphoid cells, causing immunosuppression resulting from the depletion of $\mathrm{T}$ and $\mathrm{B}$ lymphocytes. Additionally, BVDV interferes with the activity of macrophages, which promotes the occurrence of secondary infections (BROWNLIE, 2002; RADOSTITS et al., 2002).

The most commonly used techniques to detect antibodies against BVDV are virus neutralization (VNT) and immunoenzymatic assays such as ELISA. VNT is adequate for the quantification of antibodies, and is carried out by titration. However, since it is a complex and expensive test, ELISA has been used in Europe as an alternative, as it is faster and cheaper. In addition, can be applied to individual samples or serum and milk pools, especially in unvaccinated herds (HOUE et al., 2006; PRESI; HEIM, 2010; ROSSMANITH et al., 2010; STAHL; ALENIUS, 2012; BOOTH et al., 2013).

The first epidemiological study of BVDV in Paraíba was performed in 2006, a serum survey of 2,343 animals from 18 farms (THOMPSON et al., 2006). In that study, a seroprevalence of $22.2 \%$ was found and positive animals were presented in 88.9 $\%$ of the sampled farms. However, no risk factors were assessed. The identification of risk factors 
associated with BVDV infection became relevant as identified indicators were used to guide the planning of preventive and control measures used to directly decrease the dissemination of infection and minimize economic loss.

In Paraíba, over the last few years, animals with clinical symptoms suggestive of MD were treated in the Veterinarian Hospital (VH) of the Federal University of Campina Grande (UFCG), located in the city of Patos. BVDV was recently isolated in an outbreak in the city of Pombal (WEBER et al., 2014). Thus, considering that the virus was confirmed in herds in Paraíba, it is necessary to understand the epidemiology of BVDV, since the state does not have a history of vaccination against BVDV.

The goal of this study was to assess the epidemiological status of BVDV infection in bovine herds in the semiarid area of Paraíba by determining the frequency of anti-BVDV antibodies and identifying risk factors associated with the infection.

\section{Materials and Methods}

A survey was performed on files from the period between 2000 and 2013, at the Clinic for Large Animal Internal Medicine of VH/UFCG, to identify cases of suspected BVD or MD. Three herds were identified as having suspected history of the disease, two in the city of Patos and one in the city of Piancó. In the period between July 2013 and March 2014, 17 additional randomly selected farms were visited, located in the same cities or neighboring areas (Figure 1) of aforementioned locations. During those visits, blood samples were collected for the detection of antibodies, and epidemiological questionnaires were performed to collect information about variables used to analyze risk factors for the disease (Table 1). The study included 20 farms, without a history of BVDV vaccination, distributed in nine counties in the mesoregion of the Sertão of Paraíba, including Patos (three farms), Santa Terezinha (one), Itaporanga (one), Santa Luzia (three), Igaracy (one), Aguiar (three), São José de Espinharas (one), Piancó (five), and Pombal (two). This research project was previously approved by the Ethics Committee on Animal Research (CEP) of UFCG, under the protocol number 25-2012.

Figure 1. Map of the state of Paraíba showing counties investigated and their respective seropositivity frequencies.

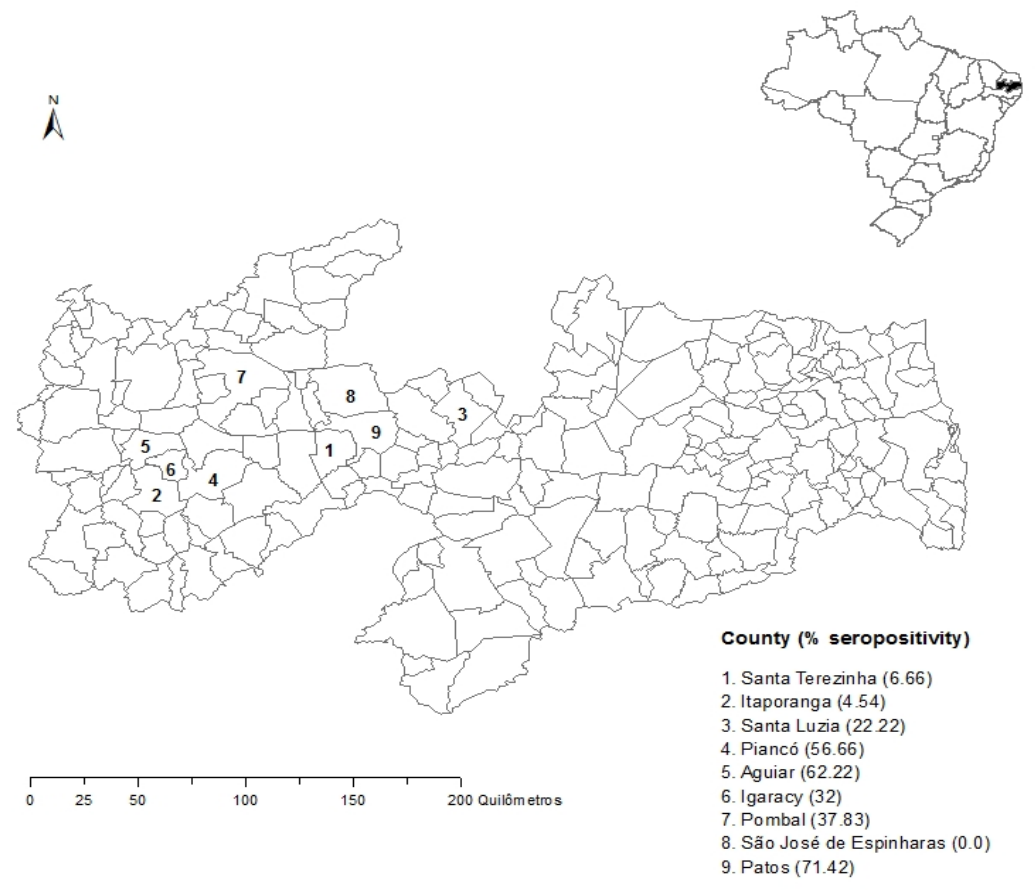


Table 1. Univariate analysis of variables most commonly associated $(P \leq 0.20)$ with BVDV seropositivity in bovines of the semiarid region of Paraíba.

\begin{tabular}{|c|c|c|c|c|}
\hline Variable & Category & $\begin{array}{c}\text { Total no. of } \\
\text { bovines }\end{array}$ & $\begin{array}{l}\text { No. of positive } \\
\text { bovines (\%) }\end{array}$ & $\mathrm{P}$ \\
\hline \multirow{3}{*}{ Type of production } & Milk & 177 & $78(44.1)$ & \\
\hline & Beef & 12 & $3(25.0)$ & \\
\hline & Mixed & 163 & $60(36.8)$ & 0.219 \\
\hline \multirow[t]{3}{*}{ Farming method } & Extensive & 113 & $47(41.6)$ & \\
\hline & Intensive & 39 & $13(33.3)$ & \\
\hline & Semi-intensive & 200 & $81(40.5)$ & 0.650 \\
\hline \multirow[t]{2}{*}{ Property area } & $\leq \mathrm{ha}^{\mathrm{a}}$ & 172 & $89(51.7)$ & \\
\hline & $>120$ ha & 148 & $36(24.3)$ & $<0.001^{*}$ \\
\hline \multirow[t]{2}{*}{ Pasture area } & $\leq 10$ ha & 183 & $77(42.1)$ & \\
\hline & $>10$ ha & 137 & $48(35.0)$ & 0.245 \\
\hline \multirow[t]{3}{*}{ Animal density } & Medium & 114 & $21(18.4)$ & \\
\hline & Low & 167 & $80(47.9)$ & \\
\hline & High & 71 & $40(56.3)$ & $<0.001 *$ \\
\hline \multirow[t]{3}{*}{ Weaning age } & Between 60-90 days & 15 & $1(6.7)$ & \\
\hline & $\leq 60$ days & 192 & $71(37.0)$ & \\
\hline & $>90$ days & 145 & $69(47.6)$ & $0.004 *$ \\
\hline \multirow[t]{3}{*}{ Milking method } & No milking & 12 & $3(25.0)$ & \\
\hline & Manual & 321 & $131(40.8)$ & \\
\hline & Mechanic & 19 & $7(36.8)$ & 0.525 \\
\hline \multirow[t]{2}{*}{ Animal purchase } & No & 27 & $7(25.9)$ & \\
\hline & Yes & 325 & $134(41.2)$ & $0.175^{*}$ \\
\hline \multirow[t]{2}{*}{ Animal exchange } & No & 252 & $87(34.5)$ & \\
\hline & Yes & 100 & $54(54.0)$ & $0.001 *$ \\
\hline \multirow[t]{2}{*}{ Weak calves } & No & 221 & $93(42.1)$ & \\
\hline & Yes & 131 & $48(36.6)$ & 0.371 \\
\hline \multirow[t]{2}{*}{ Anomalies in calves } & No & 321 & $125(38.9)$ & \\
\hline & Yes & 31 & $16(51.6)$ & 0.237 \\
\hline \multirow[t]{2}{*}{ Calf mortality } & $<5 \%$ & 314 & $115(36.6)$ & \\
\hline & $>5 \%$ & 38 & $26(68.4)$ & $<0.001 *$ \\
\hline \multirow[t]{2}{*}{ Occurrence of abortion } & No & 194 & $92(47.4)$ & \\
\hline & Yes & 158 & $49(31.0)$ & $0.003 *$ \\
\hline
\end{tabular}


continuation

\begin{tabular}{|c|c|c|c|c|}
\hline \multirow[t]{3}{*}{ Age of abortion } & No abortion & 194 & $92(47.4)$ & \\
\hline & $>3$ months & 71 & $32(45.1)$ & \\
\hline & $<3$ months & 87 & $17(19.5)$ & $<0.001^{*}$ \\
\hline \multirow[t]{2}{*}{ Return to heat } & No & 88 & $33(37.5)$ & \\
\hline & Yes & 264 & 108 (40.9) & 0.660 \\
\hline \multirow[t]{2}{*}{ Decrease in milk production } & No & 126 & $37(29.4)$ & \\
\hline & Yes & 226 & $104(46.0)$ & $0.003 *$ \\
\hline \multirow[t]{2}{*}{ Reproduction handling } & Natural breeding & 269 & $99(36.8)$ & \\
\hline & Breeding $+\mathrm{AI}^{\mathrm{b}}$ & 83 & $42(50.6)$ & $0.034 *$ \\
\hline \multirow[t]{2}{*}{ Presence of other animal species } & No & 83 & $28(33.7)$ & \\
\hline & Yes & 269 & $113(42.0)$ & 0.224 \\
\hline \multirow[t]{4}{*}{ Origin of water } & Well & 61 & $21(34.4)$ & \\
\hline & River & 62 & $22(35.5)$ & \\
\hline & Weir & 40 & $21(52.5)$ & \\
\hline & All of the above & 189 & $77(40.7)$ & 0.266 \\
\hline \multirow[t]{2}{*}{ Quarantine } & No & 272 & $105(38.6)$ & \\
\hline & Yes & 80 & $36(45.0)$ & 0.370 \\
\hline \multirow[t]{2}{*}{ Calving paddock } & No & 306 & 113 (36.9) & \\
\hline & Yes & 46 & $28(60.9)$ & $0.003^{*}$ \\
\hline \multirow[t]{2}{*}{ Restrictions on the entry of people } & No & 133 & $36(27.1)$ & \\
\hline & Yes & 219 & $105(47.9)$ & $<0.001^{*}$ \\
\hline \multirow[t]{3}{*}{ Veterinary assistance } & No & 133 & $57(42.9)$ & \\
\hline & Yes & 194 & $76(39.2)$ & \\
\hline & Occasionally & 25 & $8(32.0)$ & 0.556 \\
\hline
\end{tabular}

* Variables selected for multiple analysis by logistic regression $(\mathrm{P} \leq 0.20) ;{ }^{\mathrm{a}}$ Hectares; ${ }^{\mathrm{b}}$ Artificial insemination.

To calculate the minimum number of animals to be sampled, an expected prevalence of $50 \%$ was considered (number adopted to maximize the sample), with a confidence level of $95 \%$ and an absolute error of $6 \%$ (NOORDHUIZEN et al., 1997), using the following formula for simple random samples:

Where:

$$
n=\frac{z^{2} P(1-P)}{d^{2}}
$$

$n=$ number of sampled animals;
$Z=$ value of the normal distribution for a $95 \%$ confidence level;

$P=$ expected prevalence;

$d=$ absolute error.

The minimum number of animals to be sampled was 267; however, 359 animals were selected. All bovines in these farms were selected for blood sample collection. Blood samples were then centrifuged to obtain serum, and stored at $-70{ }^{\circ} \mathrm{C}$.

To detect anti-BVDV antibodies, we used the IDEXX BVDV p80 Ab Test, which is a commercial 
indirect ELISA kit (Pourquier Institute, Montpellier SAS, France). This kit uses a non-structural p80 protein as an antigen, and has a sensitivity and specificity of $97.6 \%$ and $97.27 \%$, respectively, according to the information of the manufacturer's validation data report. The test was performed in compliance with the manufacturer's instructions, using polystyrene 96-well plates and reading them in a spectrophotometer at a wavelength of $450 \mathrm{~nm}\left(\mathrm{~A}_{450}\right)$. The results were calculated as the percentage of inhibition, according to the following formula: $\mathrm{A} / \mathrm{N}=100 \times\left(\mathrm{A}_{450}\right.$ sample/ $\left.\mathrm{CNx}\right)$, where $\mathrm{A} / \mathrm{N}$ is the sample ratio, $\mathrm{A}_{450}$ sample is the sample to be assessed and $\mathrm{CNx}$ is the mean of the negative control. The results were interpreted as follows: samples with $\mathrm{A} / \mathrm{N}$ ratio greater than or equal to $50 \%$ were considered negative, whereas samples with an $\mathrm{A} / \mathrm{N}$ ratio less than or equal to $40 \%$ were considered positive; samples with an $\mathrm{A} / \mathrm{N}$ ratio between 40 and $50 \%$ were considered suspicious.

The analysis of risk factors was performed in two stages, univariate and multivariate analysis. For univariate analysis, each independent variable was crossed with the dependent variable (serum status of the animal). The variables with $\mathrm{P} \leq 0.2$ in the chisquare test were selected for multivariate analysis, using multiple logistic regression (HOSMER; LEMESHOW, 2000). The adjustment of the final model was verified using the determination coefficient $\left(\mathrm{R}^{2}\right)$. The collinearity between the predictor variables was verified by correlation analysis. For data with strong collinearity (correlation coefficient $>0.9$ ), one of the two was excluded from multiple analysis, according to their biological plausibility (DOHOO et al., 1996). The level of significance adopted in the multiple analysis was $5 \%$, and all analyses were performed using the program SPSS 20.0 for Windows.

\section{Results and Discussion}

Seven samples were considered suspicious and not included in analysis. Of 352 animals assessed,
$141(40.1 \% ; 95 \%$ CI $=34.9 \%-45.2 \%)$ were seropositive. Of the 20 farms evaluated, 19 (95 $\%)$ had seropositive animals, and the frequency of seropositive animals per farm varied between $4.5 \%$ and $85.7 \%$. Other studies performed in northeastern Brazil, determined BVDV frequencies of $67.3 \%$ in the city of São Luís, state of Maranhão (SOUSA et al., 2013), $65.66 \%$ in the regions of Bacabal and Pedreiras, state of Maranhão (CHAVES et al., 2009), and $72.6 \%$ in nine cities in the microregion of the Meridional Agreste, in the state of Pernambuco (CASTRO et al., 1993). The semiarid region of Paraíba showed relatively low frequency, even though it was above the $22.2 \%$ rate reported by Thompson et al. (2006), also in Paraíba. These results raise concerns, as an increase in the percentage of seropositive animals was found in regions with a history of clinical suspicion of MD, suggesting that the virus is disseminating between herds in the mesoregion of Sertão. These data indicate that frequencies of seropositive animals can be even higher in other regions of Paraíba, since the prevalence of infection can vary according to the region and factors such as bovine population density and handling.

The frequencies of seropositive animals per city are shown in Figure 1. The survey performed on the clinical files of $\mathrm{VH}$ verified that animals with a presumptive diagnosis of MD were from the cities of Piancó and Patos. These regions, together with the municipalities of Aguiar, Pombal, and Igaracy presented the highest frequency of seropositive animals in this study. It is important to highlight that in the city of Pombal the virus had been previously isolated (WEBER et al., 2014). In addition, the sale or exchange of animals is common in this region, which could contribute to the dissemination of the viral agent.

The presence of BVDV in herds induces a humoral response, resulting in the production of antibodies in animals in contact with the virus. These animals become seropositive for life, even after the elimination of the virus (HOUE, 1992). In contrast, 
vaccines do not induce a significant and long-lasting serological response in most animals. Low antibody titers with a short duration are observed when using inactive vaccines, compared to that observed with modified-live virus vaccines (VOGEL et al., 2002). However, BVDV vaccination is not performed in this region, which indicates that antibodies were associated with an infection in these herds. The fact that only inactive vaccines are licensed in Brazil confirms that serum responses were due to infection, as only live vaccines induce the production of antibodies against the NS3 protein. This means that the ELISA test will detect the response to natural infection.

According to Brownlie et al. (1989), BVDV, when present in herds, induces a high rate of seropositivity, varying between 60 and $90 \%$. Houe and Meyling (1991) stated that the presence or absence of PI animals in herds could be determined by serological analysis, since a comparative study demonstrated that in 10 herds in contact with PI animals, $87 \%$ of animals were seropositive compared to $43 \%$ seropositivity detected in nine herds not in contact with PI animals. Thus, the high prevalence of seropositive animals provides indirect evidence of the presence of PI animals. This ratio has been used as a way to obtain an early diagnosis in herds, testing a small sample, to detect antibodies against BVDV in areas where vaccination is not performed. Herein, the frequency of positive diagnosis (in 20 properties in Paraíba) varied between $4.5 \%$ and $85.7 \%$, and in six properties, this rate was above $60 \%$. With this information, further studies are required to identify PI or temporarily infected (TI) animals.

PI animals are considered the main disseminators of virus, since they are often asymptomatic, serologically negative, and continually clear the virus via secretions and excretions (FULTON et al., 2005). The clinical manifestation of MD can occur in animals up to 24 months of age, which enhances the risks of dissemination throughout the herd (RIDPATH; FLORES, 2007). The percentage of seropositive animals in properties located in cities without MD suspicion (Santa Terezinha, Itaporanga, Santa Luzia and São José de Espinharas) was lower than in that in cities where the disease was reported (Piancó, Patos and Pombal).

Table 1 shows results of the univariate analysis for risk factors. The variables selected $(\mathrm{P} \leq 0.20)$ for multiple analysis were area of the property, animal density, weaning age, animal purchase, animal exchange, calf mortality, occurrence of abortions, age of abortions, decrease in milk production, handling of reproduction, calving paddock, and restriction on the entry of people. In the final logistic regression model (Table 2), the identified risk factors were area $\leq 120$ hectares $(\mathrm{OR}=3.06)$, high animal density $(\mathrm{OR}=3.48)$, weaning age of $\leq 60$ days $(\mathrm{OR}=10.99)$, animal exchange $(\mathrm{OR}=4.95)$, calf mortality $>5 \%(\mathrm{OR}=2.33)$, and the application of natural breeding and artificial insemination $(\mathrm{OR}=$ 3.06). The final model showed a good adjustment $\left(\mathrm{R}^{2}=0.347\right)$.

Animals raised in farms with areas less than or equal to 120 hectares and with high density showed a higher risk of seropositivity compared to animals raised on farms with areas larger than 120 hectares and with a lower population density. This combination of small area and high density suggests more agglomeration and direct contact between the animals, which favors the dissemination of BVDV. Direct contact is the most efficient way to transmit the virus, especially in the presence of PI animals in the herd (NISKANEN et al., 1996). 
Table 2. Risk factors, estimated using multiple logistic regression, associated with BVDV seropositivity in cattle of the semiarid region of Paraíba.

\begin{tabular}{cccc}
\hline Variable & Odds ratio & $95 \%$ CI & P \\
\hline Area $\leq 120$ ha & 3.06 & $1.43-6.53$ & 0.004 \\
High density & 3.48 & $1.24-9.79$ & 0.018 \\
Weaning age $\leq 60$ days & 10.99 & $1.31-91.9$ & 0.027 \\
Animal exchange & 4.95 & $2.08-11.8$ & $<0.001$ \\
Calf mortality $>$ 5\% & 2.33 & $1.07-5.11$ & 0.034 \\
Use of natural breeding + artificial insemination & 3.06 & $1.22-7.67$ & 0.017 \\
\hline
\end{tabular}

$\mathrm{R}^{2}=0.347$.

Newborn ruminants show negligible gammaglobulin levels, which only increases when ingesting quality colostrum, in the right timeframe. Between 15 and 30 days of age, the levels of gammaglobulin decrease significantly, probably due to the consumption or degradation of passively transferred immunoglobulins (TIZARD, 2002). When maternal antibodies decrease, the animal quickly acquires immunological competence by initiating the endogenous synthesis of immunoglobulins (ECKERSALL, 1997). This generally occurs starting at 60 days of age, with maximum levels obtained at 150 days of age, when there is a significant increase in gammaglobulin levels, probably due to the animal's response to exposure to antigen stimuli (TIZARD, 2002; CORTESE, 2009). At approximately 60 days of age, calves start to develop their own immunity; therefore, if weaned before this period, they become more vulnerable to infectious agents present in the environment. In addition, such weaning practices can cause stress to the animal. This can explain the higher risk of seropositivity in animals weaned on or before 60 days of age.

The purchase and exchange of animals are classic risk factors for the occurrence and dissemination of infectious and parasitic diseases. In this studied region, it is common to exchange animals without performing BVDV diagnostic tests. This could be an important factor for the dissemination of the agent within herds. It is important to consider that the only farm that did not have any seropositive animals did not have a history of purchase or exchange of animals.

Even though calf mortality above $5 \%$ was identified as a risk factor, this parameter should not be identified as a risk factor, but rather a consequence of the infection, which could also be associated with improper newborn handling. However, the risk of PI calves that are part of herds with a mortality rate above $5 \%$ is real. Although they can show late clinical signs, PI animals usually have delayed growth, congenital malformations, and higher susceptibility to secondary infections (RIDPATH; FLORES, 2007). According to Brownlie (2002), agents such as type 1 bovine herpesvirus, coronavirus, Pasteurella haemolytica, Histophilus somni, Mycoplasma bovis, and Salmonella spp. are often associated with clinical BVD cases.

In the semiarid region of Paraíba, the use of natural breeding associated with artificial insemination, was also identified as a risk factor. Quincozes et al. (2007) has previously reported that the use of artificial insemination and natural breeding contributed to an increased risk of seropositivity in the state of Rio Grande do Sul. The use of artificial insemination has become increasingly common due to the growth of technical assistance programs that encourage this practice at low costs. However, several quality control measures are necessary to ensure that the assisted reproduction techniques do no facilitate viral transmission (GIVENS; WALDROP, 2004). When performed in compliance with international rules, with sanitary control of the herd, and with 
proper semen processing, insemination is a safe assisted reproduction procedure. However, in some cases, the origin and quality of the semen is unknown, making females and the herd vulnerable. Weber et al. (2014), when reporting a BVD outbreak in the state of Paraíba, suggested that one viral point of entry was the purchase of a bull and cows from Southern Brazil, or the unassisted use of semen.

Additional risk factors identified in this study could contribute to decreased prevalence of viral infections in the region. Therefore, we suggest the following measures: (a) weaning only after 60 days, a time when calves are better equipped to produce efficient responses; (b) improving the animals' living areas to decrease population density; (c) the purchase or exchange of animals should be done only after conducting a BVDV test; (d) more careful with semen purchase for artificial insemination purposes, which should only come from bulls submitted to sanitary control.

\section{Conclusion}

To avoid the transmission of BVDV in herds of the Sertão of Paraíba, it is important to mitigate risk factors identified in this study. Other epidemiological studies need to be performed at a state level, to confirm the prevalence of infection and the presence of permanently infected animals.

\section{Acknowledgements}

We are grateful to the Coordenação de Aperfeiçoamento de Pessoal de Nível Superior (CAPES) for financial support, and to Prof. Dra. Márcia Almeida de Melo for technical and laboratory support.

\section{References}

BACHOFEN, C.; VOGT, H.-R.; STALDER, H.; MATHYS, T.; ZANONI, R.; HILBE, M.; SCHWEIZER, M.; PETERHANS, E. Persistent infections after natural transmission of bovine viral diarrhoea vírus from cattle to goats and among goats. Veterinary Research, London, v. 44, n. 32, p. 1-10, 2013.

BOOTH, R. E.; CRANWELL, M. P.; BROWNLIE, J. Monitoring the bulk milk antibody response to BVDV: the effects of vaccination and herd infection status. Veterinary Record, London, v. 172, n. 17, p. 449-456, 2013.

BROWNLIE, J. Bovine virus diarrhoea virus: pathogenesis and control. In: WORLD BUIATRICS CONGRESS, 22., 2002, Hannover. Proceedings... Hannover: World Association for Buiatrics, 2002. p. 2430.

BROWNLIE, J.; CLARK, M. C.; HOWARD, C. J. Experimental infection of cattle in early pregnancy with a cytopathic strain of bovine virus diarrhoea virus. Research in Veterinary Science, London, v. 46, n. 3, p. 307-311, 1989.

CASTRO, R. S.; MELO, L. E. H.; ABREU, S. R. O.; MUNIZ, A. M. M.; ALBUQUERQUE, A. P. S. Anticorpos neutralizantes contra Pestivirus em soros bovinos no estado do Pernambuco. Pesquisa Agropecuária Brasileira, Brasília, v. 28, n. 11, p. 1327-1331, 1993.

CHAVES, P. N.; BEZERRA, D. V.; BORGES, F. C.; SOUSA, V. E.; SANTOS, H. P.; PEREIRA, H. M. Frequência e fatores associados à infecção pelo vírus da diarreia viral bovina (BVDV) em bovinos leiteiros não vacinados nas regiões de Bacabal e Pedreiras, estado do Maranhão. In: CONGRESSO BRASILEIRO DE BUIATRIA, 8., 2009, Belo Horizonte. Anais... Belo Horizonte: Associação Brasileira de Buiatria, 2009. p. 502-507.

CORTESE, V. S. Neonatal immunology. Veterinary Clinics of North American Food Animal Practice, New York, v. 25, n. 1, p. 221-227, 2009.

DOHOO, I. R.; DUCROC, C.; FOURICHON, C.; DONALD, A.; HURNIK, D. An overview of techniques for dealing with large numbers of independent variables in epidemiologic studies. Preventive Veterinary Medicine, London, v. 29, n. 3, p. 221-239, 1996.

ECKERSALL, P. D. Proteins, proteomics, and the dysproteinemias. In: KANEKO, J. J. Clinical biochemistry of domestic animals. $5^{\text {th }}$ ed. San Diego: Academic Press, 1997. p. 116-155. 
FULTON, R. W.; BRIGGS, R. E.; RIDPATH, J. F.; SALIKI, J. T.; CONFER, A. W.; PAYTON, M. E.; DUFF, G. C.; STEP, D. L.; WALKER, D. A. Transmission of bovine viral diarrhea virus $1 \mathrm{~b}$ to susceptible and vaccinated calves by exposure to persistently infected calves. Canadian Journal of Veterinary Research, Ottawa, v. 69, n. 3, p. 161-169, 2005.

GIVENS, M. D.; WALDROP, J. G. Bovine viral diarrhea virus in embryo and semen production systems. Veterinary Clinics of North American Food Animal Practice, New York, v. 20, n. 1, p. 21-38, 2004.

GROOMS, D. L. Reproductive consequences of infection with bovine viral diarrhea virus. Veterinary Clinics of North American Food Animal Practice, New York, v. 20, n. 1, p. 5-19, 2004.

GROOMS, D. L.; KEILEN, E. D. Screening of neonatal calves for persistent infection with bovine viral diarrhea virus by immunohistochemistry on skin biopsy samples. Clinical and Diagnostic Laboratory Immunology, New York, v. 9, n. 4, p. 898-900, 2002.

HOSMER, D. W.; LEMESHOW, S. Applied logistic regression. New York: John Wiley \& Sons, 2000. 375 p.

HOUE, H. Serological analysis of a small herd sample to predict presence or absence of animals persistently infected with bovine viral diarrhoea virus (BVDV) in dairy herds. Research in Veterinary Science, London, v. 53, n. 3, p. 320-323, 1992.

HOUE, H.; LINDBERG, A.; MOENNIG, V. Test strategies in bovine viral diarrhea virus control and eradication campaigns in Europe. Journal of Veterinary Diagnostic Investigation, Stanford, v. 18, n. 5, p. 427436, 2006.

HOUE, H.; MEYLING, A. Prevalence of bovine virus diarrhoea (BVD) in 19 Danish dairy herds and estimation of incidence of infection in early pregnancy. Preventive Veterinary Medicine, London, v. 11, n. 1, p. 9-16, 1991.

NISKANEN, R.; LINDBERG, A.; LARSSON, B.; ALENIUS, A. Primarily BVDV-infected calves as transmitters of the infection. In: WORLD BUIATRICS CONGRESS, 19., 1996, Edinburgh. Proceedings... Edinburgh: World Association for Buiatrics, 1996. p. 593-595.

NOORDHUIZEN, J. P. T. M.; FRANKENA, K.; VAN DER HOOF, C. M.; GRAAT, E. A. M. Application of quantitative methods in veterinary epidemiology. Wageningen: Wageningen Press, 1997. 445 p.

PRESI, P.; HEIM, D. BVD eradication in Switzerland a new approach. Veterinary Microbiology, Amsterdã, v. 142, n. 1-2, p. 137-142, 2010.
QUINCOZES, C. G.; FISCHER, G.; HÜBNER, S. O.; VARGAS, G. D.; VIDOR, T.; BROD, C. S. Prevalência e fatores associados à infecção pelo vírus da diarréia viral bovina na região Sul do Rio Grande do Sul. Semina: Ciências Agrárias, Londrina, v. 28, n. 2, p. 269-276, 2007.

RADOSTITS, O. M.; GAY, C.; BLOOD, D. C.; HINCHCLIFF, K. W. Doenças causadas por vírus e Chlamydia - I. In: RADOSTITS, O. M.; GAY, C.; BLOOD, D. C.; HINCHCLIFF, K. W. Clínica veterinária: um tratado de doenças de bovinos, ovinos, suínos, caprinos e equinos. 9. ed. Rio de Janeiro: Guanabara Koogan, 2002. p. 974-993.

RIDPATH, J. F.; FLORES, E. F. Flaviviridae. In: FLORES, E. F. Virologia veterinária. Santa Maria: UFSM, 2007. p. 582-589.

RODNING, S. P.; GIVENS, M. D.; MARLEY, M. S. D.; ZHANG, Y.; RIDDELL, K. P.; GALIK, P. K.; HATHCOCK, T. L.; GARD, J. A.; PREVATT, J. W.; OWSLEY, W. F. Reproductive and economic impact following controlled introduction of cattle persistently infected with bovine viral diarrhea virus into a naive group of heifers. Theriogenology, London, v. 78, n. 7, p. 1508-1516, 2012.

ROSSMANITH, W.; DEINHOFER, M.; JANACEK, R.; TRAMPLER, R.; WILHELM, E. Voluntary and compulsory eradication of bovine viral diarrhoea virus in Lower Austria. Veterinary Microbiology, Amsterdã, v. 142, n. 1-2, p. 143-149, 2010.

SANDVIK, T. Laboratory diagnostic investigations for bovine viral diarrhea virus infections in cattle. Veterinary Microbiology, Amsterdam, v. 64, n. 2-3, p. 123-134, 1999.

SOUSA, V. E.; BEZERRA, D. C.; CHAVES, N. P.; SANTOS, H. P.; PEREIRA, H. M. Frequência de anticorpos e fatores de risco associados à infecção pelo vírus da diarreia viral bovina (BVDV) e herpesvírus bovino tipo 1 (BoHv-1) em fêmeas bovinas leiteiras criadas em sistema de produção semi-intensivo. Revista Brasileira de Medicina Veterinária, Rio de Janeiro, v. 35, n. 1, p. 21-25, 2013.

STAHL, K.; ALENIUS, S. BVDV control and eradication in Europe an-update. Japanese Journal of Veterinary Research, Hokkaido, v. 60, p. S:31-39, 2012. Supplement.

TIZARD, I. R. Imunidade do feto e do recém-nascido. In: TIZARD, I. R. (Ed.). Imunologia veterinária: uma introdução. São Paulo: Roca, 2002. p. 233-246. 
THOMPSON, J. A.; LEITE, R. M. H.; GONÇALVES, V. S. P.; LEITE, R. C.; BANDEIRA, D. A.; HERRMANN, G. P.; MOREIRA, E. C.; PRADO, P. E. F.; LOBATO, Z. I. P.; BRITO, C. P. T.; LAGE, A. P. Spatial and hierarchical variances and age covariances for seroprevalence to Leptospira interrogans serovar hardjo, BoHV-1 and BVDV for cattle in State of Paraiba, Brazil. Preventive Veterinary Medicine, London, v. 76, n. 3-4, p. 290-301, 2006.

VOGEL, F. S. F.; FLORES, E. F.; WEIBLEN, R.; MAYER, S. V.; QUADROS, V. L.; OLDONI, I.
Magnitude, duração e especificidade da resposta sorológica em bovinos vacinados contra o vírus da diarréia viral bovina (BVDV). Ciência Rural, Santa Maria, v. 32, n. 1, p. 83-89, 2002.

WEBER, M. N.; MÓSENA, A. C. S.; SIMÕES, S. V. D.; ALMEIDA, L. L.; PESSOA, C. R. M.; BUDASZEWSKI, R. F.; SILVA, T. R.; RIDPATH, J. F.; RIET-CORREA, F.; DRIEMEIER, D.; CANAL, C. W. Clinical presentation resembling mucosal disease associated with hobilike pestivirus in a field outbreak. Transboundary and Emerging Diseases, Oxford, v. 63, n. 1, p. 92-100, 2014. 
